\title{
CALVINISTIESE PERSPEKTIEF
}

\section{CALVINISTIESE REAKSIES OP DIE HUIDIGE WERELDVEROORDELING VAN SUID-AFRIKA.}

Ook in my medewerking aan ons Gereformeerde Kerk se Sinodale Deputaatskap omtrent die rasse-vraagstuk, wat binnekort sy rapport vir die volgende sinode sal finaliseer, het ek in noue aanraking gekom met die gebrokenheid van ons Calvinistiese reaksie op die sogenaamde tradisionele Suid-Afrikaanse rassebeleid, asook met die verwilderdheid in ons nasionale reaksie op die universele wêreldveroordeling van daardie beleid.

Hierdie verwarring is eensdeels 'n gevolg van die geweldig vinnige veranderinge op hierdie gebied in die huidige wêreld-situasie, en anderdeels van 'n fundamentele teenstrydigheid in ons eie standpunt en 'n noodlottige eensydigheid in die sogenaamde wêreld-mening.

Om met eersgenoemde faktor in die oorsaaklike kompleks wat hierbo met die woord ,anderdeels" ingelei is, te begin: die teenstrydigheid in ons eie standpunt ten opsigte van die rassevraagstuk word nog verder gekompliseer deur 'n geheel verouderde maatstaf wat ons toepas om ons eie gewete te sus.

Die teenstrydigheid bestaan hierin dat ons, wat ons blanke Afrikanerdom betref, nasionalisme aanvaar en vreemde oorheersing as ongeregverdigde imperialisme verwerp, terwyl ons, wat die nie-blankes in Suidelike Afrika betref, hulle nasionalisme as oproerig veroordeel, aan hulle selfs die vooruitsig op volle nasionale selfbeskikking ontsê en ons eie oorheersing oor hulle tot in die onafsienbare toekoms in die vorm van blanke baasskap regverdig en nie as imperialisme beskou nie. Dit geld ook vir die apartheid van dr. Malan en die afsonderlike ontwikkeling van $\mathrm{dr}$. Verwoerd. Want ook laasgenoemde hou geen belofte van of vooruitsig op selfbeskikking vir die nie-blankes in nie, nieteenstaande beweringe tot die teendeel van wie ook al - dit sou ek graag voor enige instansie wil bewys.

Hierdie baasskap van ons probeer ons dan te regverdig, deur die verouderde vergelykingsmaatstaf waarvan ek bo gepraat het. Ons wil naamlik te kenne gee dat ons inderdaad baie edelmoedige base is deur die huidige toestand van 
ons nie-blankes te vergelyk met wat dit was voordat ons baasskap begin het, of met die omstandighede van die naturelle-gemeenskappe in die res van Afrika of selfs van nie-blankes in ander wêrelddele of van proletariërs oor die algemeen.

Dit is egter ' $n$ verouderde maatstaf, omdat die moderne wêreld as maatstaf gebruik die lewensomstandighede van die vol-geïndustrialiseerde gemeenskappe van vandag, m.a.w., om net na persoonlike inkomste te kyk, die vergelyking is nou nie meer tussen die $£ 30$ per jaar van ons huidige naturelle en hulle $\mathfrak{f 1 0}$ per jaar van 'n half-eeu gelede nie,

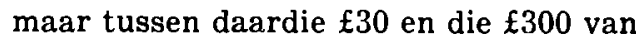
'n gemiddelde Westers-blanke gemeenskap. Want die wêreld het nou besluit om welvaart universeel te maak, omdat dit met die moderne tegniek vir die eerste maal in die wêreldgeskiedenis gedoen kan word, en ook omdat die wêreld weer eenheidsbewus geword het.

So veel voorlopig oor die gebreke in ons eie standpunt. En nou nog korter oor die eensydigheid van die sogenaamde wêreldmening oor ons rassebeleid en oor die rassevraagstuk in die algemeen.

Hierdie eensydigheid is veral hierin geleë, dat ten eerste, omdat die tyd van imperialisme en kolonialisme ten einde geloop het, die heerskappy van een volk oor ' $n$ ander in alle omstandighede veroordeel word, terwyl dit tog vasstaan op grond van Skrif en historie beide dat die menslike kultuurtaak in sekere tydperke en omstandighede sodanige heerskappy vereis. Ten tweede is dit 'n eensydigheid om die beginsel van nasionale selfbeskikking te verabsolu- teer asof alle volke of volkies in die moderne wêreld op hul eie bene kan staan. En in die derde plpek is dit noodlottig eensydig om in die emansipasie-proses individuele vryheid en gelykheid op die spits te dryf ten koste van nasionale verskeidenheid en saamhorigheid, wat ook tot 'n mate 'n rassegrondslag het.

Hierdie eensydighede tree veral sterk op die voorgrond by nie-Calvinistiese skrywers soos in die pas verskene en origens baie verdienstelike werk van die jong Amerikaanse skrywer Ritner, getiteld „The Death of Africa". Daarenteen kry ' $n$ mens ook by hulle by uitsondering nog 'n meer gebalanseerde beskouing soos by uitstek in ' $n$ ander resente werk: "Schuld der Weiszen"? van die meer bejaarde en wêreldervare Duitse wetenskaplike Drascher.

Maar ook die Nederlandse Calvinistiese skrywers maak hulle steeds meer aan die genoemde eensydighede skuldig. 'n Sterk voorbeeld hiervan is die pasverskene "Apartheid and Discrimination" van die jong Nederlandse regsgeleerde dr. K. L. Roskam.

Dit is dan ook opmerklik dat hoewel hierdie werk as 'n doktorsproefskrif aanvaar is aan die Amsterdamse Vrye Universiteit, dit nie alleen afwyk van die beskouinge van prof. dr. H. Dooyeweerd, maar daar nie eens melding van maak nie.

Prof. Dooyeweerd self het daarenteen tot nog toe selfs meer prinsipieel as prof. Bavinck die betekenis van rasfaktore en ook van nasionaliteit vir die staatsbeleid in ag geneem, hoewel ook hy, soos moderne Nederlanders in die 
algemeen, nie voldoende deurdronge is van die betekenis van nasionalisme nie.

Tog sê prof. Dooyeweerd o.a. die volgende in verband met ons Suid-Afrikaanse rassevraagstuk in die gebrekkig vertaalde Engels van sy groot werk: ,A New Critique of Theoretical Thought", vol. III, 1957, pp. 495 vv.: "The races (of mankind) are grounded in the biotic blood relationship and possess fundamentally different mental, political, and cultural dispositions and potentialities."

"It is undeniable that up till now the cultural and political abilities of the negro have proved to be relatively small in comparison with those of the white and yellow races, though there are remarkable individual exceptions, and though we must not forget that hereditary dispositions are flexible and capable of disclosure by a good education.

This may give rise to very difficult political problems in States like the South African Union where the ruling white race is confronted with a majority of primitive ethnical groups of black race, of mixed breed, etc.. It is difficult to see how in the near future a real national political unity could arise in which all of these different racial groups are integrated. And here again it appears that the natural law ideas of the freedom and equality of men cannot be legally realized without an adequate historical political basis. Such a basis is certainly not present so long as a majority of black people are still in a condition of primitive culture. At the same time it must be established that the condition of such a body politic in which the majority of the people are placed under the guardianship of a white minority and are not really integrated with the latter into a national unity, is extremely precarious".

„A real political racial problem can only arise when in the same State there exist more or less sharply isolated racial types that have not been assimilated in a bio-cultural respect".

"(In such a situation) the various contrasting interests of the mutually hostile groups of subjects must be carefully balanced against each other according to the criterion of the public juridical interest. And this implies that also the different cultural positions of the ethnical groups within the political totality should be considered, though at the same time the cultural level of under-developed groups should be elevated as much as possible. By means of levelling individualistic-Humanistic standards of justice we can never solve a political racial problem."

Hieruit blyk dat prof. Dooyeweerd se opvatting prinsipieel gegrond en ook taamlik goed gebalanseerd is. Tog beskou ook hy 'n beleid van permanente blanke baasskap as ,a tyrannical excess of power."

En dit geld ongetwyfeld van die huidige apartheidsbeleid, hoewel 'n egte en radikale beleid van afsonderlike nasionale ontwikkeling op grondslag van etniese samehorigheid wat gerig is op nasionale selfbeskikking vir alle lewensvatbare nasionaliteite,geregverdig sou wees en ook wel uitvoerbaar is.

Maar hiertoe sal ons eers kan oorgaan as ons besef dat ons deelname 
aan die internasionale wêreld-gemeenskap in die huidige situasie algaande meer onmoontlik word, omdat die wêreld as geheel besig is om ons uit te stoot, en wel nie bloot vanweë die woelinge van agitators of wanvoorstellinge van die wêreldpers nie, maar omdat ons nasionale beleid, wat betref al ons blanke partye, gerig is op die bestendiging van blanke baasskap.

Daarom beklemtoon ek eers hierdie skokkende feit, voordat ek moontlik by 'n later geleentheid oorgaan tot 'n meer konstruktiewe benadering van hierdie vraagstuk van lewe en dood, vir die Afrikanerdom en vir Afrika.

En as ek sê dat die wêreld as geheel besig is om ons in die ban te doen, dan dink ek nie in die eerste plek aan ons isolasie in die Statebond of aan die aangroeiende boikotbeweging teen ons en selfs nie by uitstek aan die Verenigde Nasies nie, hoewel laasgenoemde ons binnekort met mening tot verantwoording sal roep, veral wat Suid-Wes$\Lambda$ frika betref. Nee, ek het daarby in gedagte die heersende gesindheid in alle lande van die wêreld, feitlik sonder uitsondering, behalwe miskien in SuidRhodesië en Portugal, wat egter self nie, soos ons, blanke baasskap as amptelike beleid verkondig nie. Daar is inderdaad slegs een wetgewende gesag in die ganse wêreld wat ons beleid ná Sharpeville goedgekeur het, en dit is een van die 24 ,state" van die Verenigde State se vyftigtal waarin geslagtelike gemeenskap van nie-blankes met blankes nog verbode is. Selfs Afrika Suid van die Sahara het ons vanjaar as geheel die rug toegedraai, aangesien blanke baasskap daar vanjaar Noord van die Sambesie finaal beëindig word. En die nuwe swart state van Afrika sluit vriendskap met Wes en Noord en Oos teen ons, ook op handelsgebied.

Terwyl ons besig is om selfs ons blanke vriende in die Statebond te verloor, is swart Afrika, wat ons gehoop het om te lei tot modernisering, besig om vennootskap te verkry met ons eie blanke moederlande, wat ons reeds alleen daarom in die toekoms nie meer sal durf of kan bevriend nie, omdat hulle alleen met toestemming van hulle swart vennote daartoe sal kan besluit, aller eers in die Wes-Europese Tol-verbond waartoe Engeland waarskynlik ook spoedig sal toetree.

Dit wat Wes-Europa betref : van die kommunistiese en gekleurde en SuidAmerikaanse state hoef 'n mens in hierdie verband nie eens te praat nie. Maar ook Noord-Amerika het nou as beleid neergelê om nie meer regeringe te steun wat diktatoriaal of rasdiskriminerend optree nie. En die ganse georganiseer. de Christendom beskou ons beleid as ' $n$ belemmering vir die Evangelie, net soos die georganiseerde wêreld-demokrasie dit beskou as 'n gevaar vir die wêreld. vrede en 'n struikelblok vir wêreldver. eniging en vryheid, nieteenstaande die algemene versobering vanweë die tragikomiese Kongo-moles.

\section{J. DU PILESSIS.}

P.U. vir C.H.O.

(Positiewe stelling in volgende uitgawe - Red.) 